\title{
SBAJA A NOVEL FOLIAR APPLIED GROWTH AND YIELD ENHANCER IN
} MALAYSIA

\author{
SBAJA, UM NOVO POTENCIADOR DE CRESCIMENTO FOLIAR APLICADO E DE \\ RENDIMENTO NA MALÁSIA
}

\section{Mohd Izzat SHAFIEE ${ }^{1}$; Burhanuddin A. BAKI ${ }^{2}$; Mohammad Moneruzzaman KHANDAKER $^{3 *}$; Muhammad Shakirin MISPA ${ }^{1}$; Baki Hj BAKAR ${ }^{1}$; Amru Nasrulhaq BOYCE $^{1}$; Johari M. SAAD ${ }^{4}$; Tengku Abdul AZIZ ${ }^{4}$}

1. Institute of Biological Sciences, Faculty of Science, University of Malaya, Kuala Lumpur, Malaysia; 2. Dept. Philosophy and Civilization, School of Humanities, Universiti Sains Malaysia, 11800 Minden, Penang, Malaysia 3. School of Agriculture Science and Biotechnology, Faculty of Bioresources and Food Industry, Universiti Sultan Zainal Abidin, Besut Campus, 22200 Besut, Terengganu, Malaysia; 3. iRX Sdn Bhd, 10 Jalan Nilam 1/1, Subang Hi-Tech, 47500, Kuala Lumpur, Malaysia

\begin{abstract}
Product efficacy testing during 2006 to 2010 with SBAJA (a novel scientifically formulated foliar-spray growth and yield enhancer) in the greenhouse and multi-location field trials registered measurable increase in chlorophyll contents, robust and healthier crop growth and increased yield and biomass production. In field trial, rice plants receiving normal NPK fertilizer at the rates of 100:50:30 served as control and spray treated with SBAJA at 40 and 60 days after sowing (DAS). All the experiments were laid out in Randomized Complete Block (RCB) Design and replicated five times. Tiller number and panicle characteristics; length, weight, number of grains, number of filled grains were significantly increased with 1:300 SBAJA treatment. In addition, 1000 grain weight and rice yield increased significantly with SBAJA treatments. Normal fertilizer applications in field trials augmented with SBAJA in 2008-2010 in the Selangor North West Project (SNWP), registered measurable increase in rice yields by 25-30\% from $6.2-6.5$ tons/ha to $7.8-8.9$ tons/ha. It is concluded that foliar spraying with SBAJA at 40 and 60 days after sowing increased growth and yield of rice under green house and field conditions.
\end{abstract}

KEYWORDS: SBAJA. Growth. Yield. Rice. Malaysia.

\section{INTRODUCTION}

Rice is the staple food for more than half of the world's population, influences the livelihoods and economies of several billion people and for hundreds of millions it is the only thing between them and starvation (IRRI, 2006). Rice production is the most important source of employment and income for rural Asians. For 700 million Asians surviving on incomes of less than one dollar a day rice can account for as much as 70 percent of their daily calories and 40 percent of their income (IRRI, 2006, 2008). In 2003, approximately 151 million hectares were cultivated worldwide, of which Asia accounted for some 138 million hectares, constituting 90 percent of global rice production (BAMBARADENIYA; AMERASINGHE, 2003). It is important to increase the yield per hectare of rice by applying modern agricultural techniques; using hybrid seeds, irrigation, weed control, insecticides and pesticides, as well as fertilization practices (DOBERMANN et al., 2004). We have developed a yet-to-be-patented propriety tentatively known as SBAJA ${ }^{\mathrm{TM}}$, a growth and yield enhancer for rice in the form of liquid foliar spray, comprising of an organic blend of emulsified, triacontanol, plant extracts, and micro-molar concentrations of the macro- and micronutrients required, in an aqueous solution including natural chelating agents, humic acid, fulvic acid, and a quality spreader/sticker synergist. Triacontanol $\left[\mathrm{CH}_{3}\left(\mathrm{CH}_{2}\right) 28 \mathrm{CH}_{2} \mathrm{OH}\right]$ is a straight chain fatty alcohol of 30 carbon atoms and exist as constituent of cuticular waxes and beeswax. Triacontanol has recently been recognized as a potent enhancer of photosynthesis and as a plant growth promoter and regulator (CHEN et al., 2002). Khandaker et al (2013a) reported that application of 1-Triacontanol increased the leaf chlorophyll content and net photosynthetic rate. It has great stimulatory effect on several enzyme activities in various plant growth processes and photosynthesis leading to enhancement of plant biomass growth and crop yield (IVANOV; ANGELOV, 1997).

A foliar spray technique was chosen for this trial because it can be designed to meet the crop's specific needs. It has long been established that plant leaves and stems are capable of absorbing micro-and macronutrients through a process called foliar feeding. Foliar feeding has been reported to stimulate plant roots to become more efficient in the uptake of all nutrient requirements. Foliar application growth regulators increased the net assimilation rate and carbohydrate concentration in the plant parts (KHANDAKER et al., 2012). 
Furthermore, it is an economical way of supplementing the plant's nutrients when they are in short supply or unavailable from the soils and it has been shown that the efficiency of foliar application is three-five folds greater than soil-applied fertilizers, and can thus significantly reduce the amount of fertilizer usage. In many cases aerial spray of nutrients is preferred, and this gives quicker and better results than the soil application (JAMAL et al., 2006). It has been reported that foliar application of kinetin improved the plant physiological activities (MONERUZZAMAN et al., 2010). Recently, foliar application of nutrients has become an important practice in the production of crops while application of fertilizers to the soil remains the basic method of feeding the majority of the crop plants. Fang et al. (2008) reported the effects of a foliar application of zinc, selenium and iron fertilizers on nutrient concentration and yield of rice grain. It has been reported that foliar application nutrient solution increased the net photosynthesis as well as yield of salt stress rice (SULTANA et al., 2001).

This study represents the effects of applications of SBAJA, a novel scientifically formulated non-toxic foliar-applied and eco-friendly photosynthesis and growth enhancer on (i) chlorophyll contents, photosynthetic rates, growth, yields and yield components of rice; and (ii) impacts of SBAJA application on rice productivity and national food security in Malaysia. The aims of this study were to investigate the effects of SBAJA on growth and yield of MR 220 rice (Oryza sativa L. var MR 220) under greenhouse and field conditions.

\section{MATERIAL AND METHODS}

\section{Greenhouse experiments}

Pot experiments were carried out under natural illumination and environmental conditions in the greenhouse at the Institute of Biological Sciences, University of Malaya, Kuala Lumpur, Malaysia in 2006 -2007 to assess crop growth and yields of rice var. MR 220 as influenced by SBAJA applications. Soils for pot experiments were collected from the Sawah Sempadan rice plantation area located on a flat coastal plain in the Northwest Selangor Agriculture Development (PBLS), under the districts of Kuala Selangor and Sabak Bernam at latitude 3035 " 45 and longitude 101005 " 52. The soil texture was clay loam, while the texture of surface layers ranged from clay loam to clay. The soil is defined as Jawa series and was classified as clayey, mixed isohyperthermic sulfic tropaquept. In green house conditions, we carried out two experiments. In first experiment, only four dilutions of SBAJA were tested for leaf chlorophyll content. SBAJA concentrates were diluted in water $(\mathrm{v} / \mathrm{v}) 0$ (only water), 1:200, 1:300, and 1:400. In second experiment, rice plants are sprayed with 0 fertilizer (T1), normal NPK fertilizer at the rates of 100:50:30 (T2) and normal fertilizer plus foliar SBAJA (T3). SBAJA was applied at 20,40 and 60 days after transplant (DAT).

\section{Field experiments}

Extensive multi-location field trials carried out with normal fertilizer applications augmented with SBAJA in 2008-2010 seasons involving 100 farmers and 200 ha in the granaries of Selangor North West Project (PBLS), KADA in Kelantan and MADA, in Kedah. Rates and time of Applications: SBAJA concentrates were diluted in water $(\mathrm{v} / \mathrm{v})$ 1:300. Rice plants receiving normal NPK fertilizer at the rates of 100:50:30 served as control and spray treated with SBAJA at 40 and 60 days after sowing (DAS).

\section{Chlorophyll content}

Total chlorophyll content in the leaves of plant was recorded using with IRRI Leaf Colour Chart and SPAD meter (Konica-Minolta Model 502). Fresh samples of rice leaves were analyzed for pigment contents. Chlorophyll concentration $(a, b$ and total) of these leaves, were determined according to Arnon (1949).

\section{Measurement of growth and yield parameters/components}

The clonal growth data (plant height and tillers number $\mathrm{m}^{-2}$ ) of the rice crop were recorded at 25, 45 and 75 DAS and at harvest, while the yield and yield components data (panicle number $\mathrm{m}^{-2}$, panicle length, $\%$ of filled and unfilled grains, 1000 grains weight, grain yield $\mathrm{m}^{-2}$ ) were recorded at harvest. The heights of ten plants at random were taken in each subplot. Hills included all above ground plant material panicle length, number of grains per panicle, no. and unfilled grain percentage, panicle weight, plant height, tiller number, length of flag leaves, 1000 grain weight, yields (1 acre), and yields (tons/ha) were determined (ESFEHANI et al., 2005). For the yield and yield components five one $\mathrm{m}^{-2}$ quadrates were placed at random but diagonally in each subplot where the crop cutting tests (CCT) were carried out. The CCT were also carried in other farmers' fields where similar SBAJA applications to the rice crop were made. 


\section{Experimental design}

In green house, the experiments were laid out in a randomized complete block design (RCBD) with four treatments for experiment one (1) and three treatments for experiment two (2) with three different doses and five replications. For field experiments in different areas, randomized complete block design (RCBD) having split-plot arrangement used in the experiment which was replicated in thrice. Each 1.2 ha plots were divided into 2 subplots of 0.3 ha each. The pooled data were statistically analyzed with MSAT-C statistical software and subsequently using Least Significant Difference (LSD) test for comparing the treatment means.

\section{RESULTS AND DISCUSSION}

Greenhouse experiments - SBAJA application on leaf chlorophyll content of rice (Oryza sativa $L$. var. MR220)
Leaf chlorophyll content, a good indicator of photosynthesis activity, mutations, stress and nutritional state, is of special significance to precision agriculture. Hansen and Schjoerring, (2003) reported that leaf chlorophyll content altered the leaf transmittance and reflectance in the visible region. It has been reported in the green house experiments, that the chlorophyll content of rice leaves significantly affected by doses of SBAJA (Figure 1).

Results showed that the highest chlorophyll content ( $a, b$ and total) was recorded in 1:300 dilution treatment, whereas, the lowest chlorophyll content was control treatments. Our results are supported by the results of Peng et al. (1995), who reported that leaf chlorophyll content had a significant effect on photosynthetic rate and grain yield of rice. It was also reported that net photosynthesis increased with chlorophyll content (Khandaker et al., 2013b).

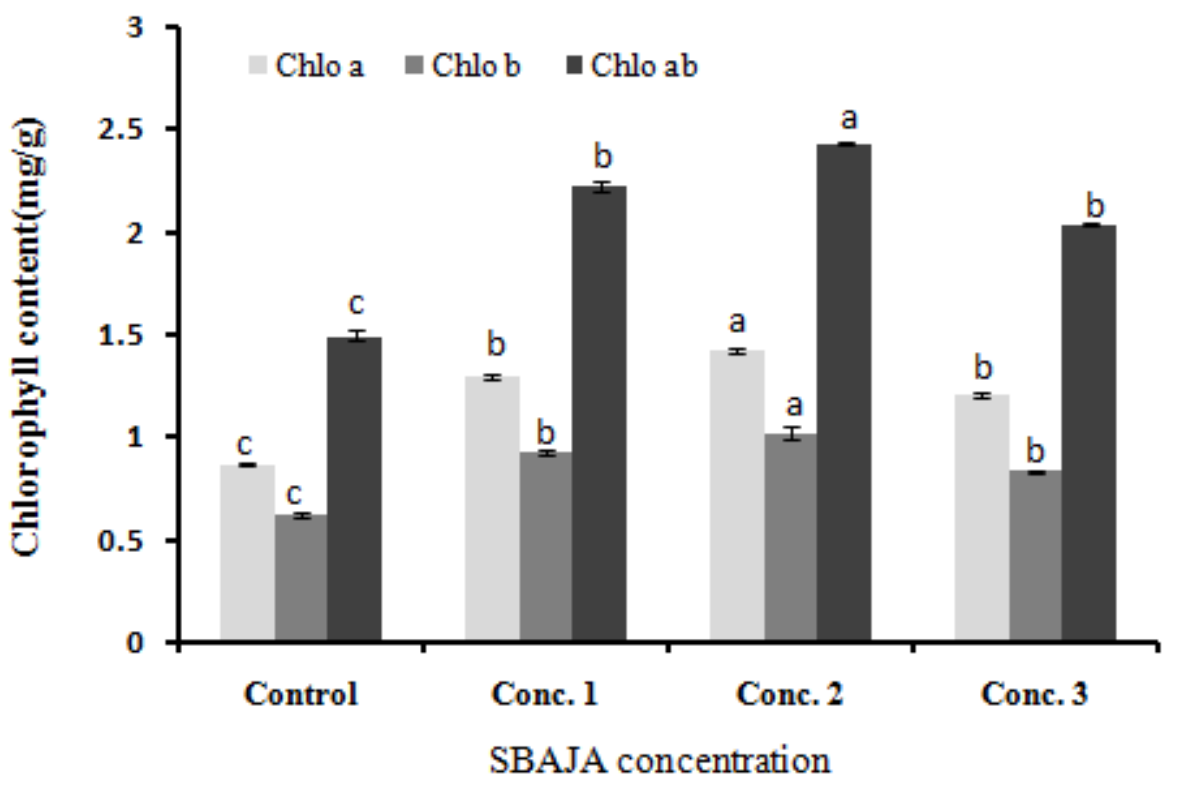

Figure 1. Effect of different concentration of SBAJA on chlorophyll content of MR220 rice variety at 40 days after sowing under green house condition.

\section{Greenhouse experiments - SBAJA application on growth and yields of rice (Oryza sativa $L$. var. MR220)}

The foliar application of SBAJA had significant effect on the number of tiller/genet (Figure 2, A). Our greenhouse results showed that, maximum tiller number was recorded $\mathrm{T} 3$ treatment (rice + NPK fertilizer + SBAJA) at different days of observations, while minimum number of tiller/genet was recorded in $\mathrm{T} 1$ treatment (rice control). This might be due to the fact that SBAJA treated rice plant get more nutrients which in return produced more tillers/genet. Secondly it might be due to that crop response was more to favorable environment in term of increased vegetative growth like tillers production. Our results shows that foliar fertilizer meant for rice improved tillering and produced the highest number of fertile panicles. These results are in the conformity with those of Dafen et al. (1999), who reported that number of tillers $\mathrm{m}^{-2}$ increased with foliar application of Potash, similarly Shah and Saeed (1989) also reported that foliar spray of urea increased the number of productive tillers. 

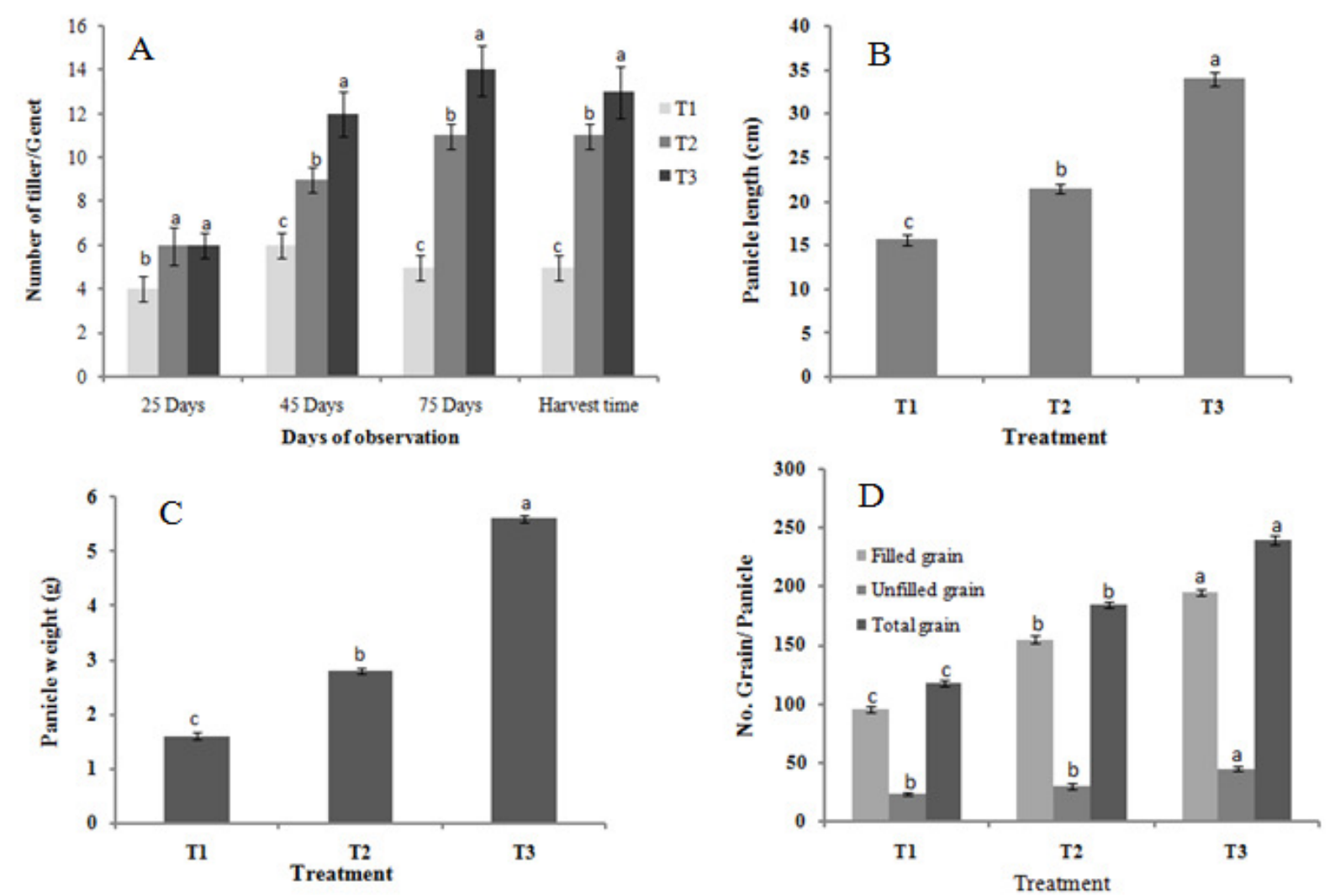

Figure 2. Mean number of tillers per genet (A), panicle length $(\mathrm{cm})(B)$, panicle weight $(\mathrm{g})(\mathrm{C})$, no. grain (D) of rice var. MR 220 plants at 25, 45, 75 days and harvest time as influenced by fertilizer and SBAJA applications. T1-rice control; T2-rice + NPK fertilizer; T3-rice + NPK fertilizer+SBAJA.

Recently, it has been reported that a small amount of nutrients (nitrogen, potash or phosphate) applied by foliar spraying increases significantly the yield of crops (HAQ; MALLARINO, 2000). It has been shown in our study that, foliar application of SBAJA produced a significant effect on panicle characteristics. The results shows that, T3 treatment also produced longest panicle than the $\mathrm{T} 2$ and $\mathrm{T} 1$ treatments and these differences were significant among the treatments (Figure 2, B). Application of SBAJA may be supply more nutrient to the plants, thus the nutrient takes part in panicle formation as well as panicle elongation. Chopra and Chopra (2004) reported that nitrogen had significantly effects on yield attributes such as plant height, panicle plant ${ }^{-1}$ and 1000 -seed weight with increasing levels of $\mathrm{N}$ up to $120 \mathrm{~kg} \mathrm{~N}^{-1}$ in rice. The highest panicle weight was recorded in $\mathrm{T} 3$ treatment followed by $\mathrm{T} 2$ treatment, while, the lowest panicle weight observed with T1 (Figure 2, C). Our results are supported by the findings of Soylu et al. (2005) and Kenbaev and Sade (2002), they reported that significant increase in number of panicles $\mathrm{m}^{-2}$ with foliar application of different micronutrients individually or in combination.
Similarly to panicle weight, number of grain/ panicle was also significantly affected by SBAJA. Results showed that T3 treatment (with SBAJA) produced the highest number of grain/ panicle, whilst, the rice plants which did not receive any SBAJA nutrient recorded the lowest number of grain/ panicle (Figure 2, D). SBAJA applications registered robust and healthier crop growth vis-à-vis the control (Figure 3). Treated rice plants recorded higher values of panicle weight and length; better grain filling/panicle; number of filled grain/panicle; total number and weight of grain/panicle; and crop yields. Our results are supported by findings of Fang et al. (2008), who reported that foliar application of zinc, selenium and iron fertilizers increased grain yield.

\section{Field trials-SBAJA on growth and yields of rice (Oryza sativa $L$, var.MR220)}

Tejada and Gonzalez (2004) reported that the foliar fertilization with a byproduct rich in humic substances with macro-and micronutrients increased the concentration of micronutrients $\mathrm{Fe}$, $\mathrm{Cu}, \mathrm{Zn}$ and $\mathrm{Mn}$, and macronutrients $\mathrm{N}, \mathrm{P}$, and $\mathrm{K}$ in leaves up taken by plants. Invariably, SBAJA 
applications registered better, healthier and more robust crop growth compared to those in the control plots. There were measurable time-mediated differences in chlorophyll content of rice (Oryza sativa L. var.MR220) with SBAJA treatments vis-àvis the control.

Table 1. Effects of SBAJA application on chlorophyll contents of rice (Oryza sativa L. var. MR 220) leaves.

\begin{tabular}{lcccccc}
\hline \multicolumn{7}{c}{ PLOTS No } \\
\hline DAS & A & B & C $*$ & D & $\mathbf{E}^{*}$ & F \\
\hline 60 & $40.12 \mathrm{a}$ & $42.80 \mathrm{a}$ & $27.40 \mathrm{a}$ & $41.92 \mathrm{a}$ & $25.60 \mathrm{a}$ & $40.16 \mathrm{a}$ \\
75 & $37.30 \mathrm{a}$ & $29.37 \mathrm{~b}$ & $21.80 \mathrm{~b}$ & $34.92 \mathrm{~b}$ & $19.80 \mathrm{~b}$ & $35.05 \mathrm{~b}$ \\
85 & $28.15 \mathrm{~b}$ & $29.30 \mathrm{~b}$ & $17.80 \mathrm{~b}$ & $29.80 \mathrm{c}$ & $17.20 \mathrm{~b}$ & $27.60 \mathrm{c}$ \\
95 & $17.60 \mathrm{c}$ & $15.50 \mathrm{c}$ & $10.50 \mathrm{c}$ & $16.40 \mathrm{~d}$ & $10.20 \mathrm{c}$ & $16.20 \mathrm{~d}$ \\
\hline
\end{tabular}

Control* (no SBAJA application). Means within the same column followed by the same letter do not differ significantly according to the LSD test at $\alpha=0.05(\mathrm{~N}=25)$.

At 60 DAS, the SPAD meter readings registered values ranging from 40.12 to 42.80 compared with $25.60-27.40$ in plots receiving normal fertilizer treatment. The parallel figures for rice plants in treated plot at 95 DAS were 15.50 17.60 whereas in the control plots these were 10.20 10.50 (Table 1). Islam et al. (2009) reported that application fertilizer increase the chlorophyll content of rice leaves. They also stated that Leaf chlorophyll content had a strong contribution to grain yield of rice. Foliar fertilizer application to the leaves is the most efficient way to get food nutrients to crop for it produce maximum yield and quality. Nicoulaud and Bloom (1996) reported that most plants absorb foliar applied urea rapidly and hydrolyze the urea in the cytosol.

Lin and Zhu (2000) stated that foliar spraying of regent at heading stage increased grain yield as a result of increasing grain number per panicle compared with control, leaf senescence was inhibited and leaf chlorophyll and photosynthesis were increased by foliar application of regent at heading stage. It also been reported that supplementary foliar fertilization during crop growth can improve the mineral status of plants and increase the crop yield (KOLOTA; OSINSKA, 2001). The biological yield of biomass revealed a significant increase with the foliar application of nutrients. Sadana et al. (2002) also reported that yield of dry matter increased with foliar application of $\mathrm{Mn}$. From the results of field trial, it was observed that SBAJA application promotes culms and root growth. SBAJA applications registered higher values of panicle weight and length; better grain filling/panicle; number of filled grain/panicle; total number and weight of grain/panicle; and crop yields (Table 2).

Table 2. Yield and yield components of rice var. MR 220 treated with SBAJA in small-scale farmers-managed field trials (10ha) (2008-2010) (6 seasons) in Tanjung Karang granary, Selangor, Malaysia.

\begin{tabular}{|c|c|c|c|c|c|c|c|c|}
\hline $\begin{array}{l}\text { MR220 } \\
\text { Variety } \\
\text { ton/ha }\end{array}$ & $\begin{array}{l}\text { Panicle } \\
\text { no/sq.m }\end{array}$ & $\begin{array}{c}\text { Panicle } \\
\text { Length }(\mathrm{cm})\end{array}$ & $\begin{array}{l}\text { Panicle } \\
\text { Weight (g) }\end{array}$ & $\begin{array}{l}\text { No. Filled } \\
\text { grain }\end{array}$ & $\begin{array}{l}\text { No. Unfilled } \\
\text { grain }\end{array}$ & $\begin{array}{l}\text { Total no. } \\
\text { grain }\end{array}$ & $\begin{array}{l}1000 \\
\text { grain wt }\end{array}$ & $\begin{array}{l}\text { Yield } \\
\text { ton/ac }\end{array}$ \\
\hline \multicolumn{9}{|c|}{ 2008field trials } \\
\hline $\begin{array}{l}\text { Control } \\
7.09 \mathrm{~b}\end{array}$ & $314 \mathrm{a}$ & $26.2 \mathrm{~b}$ & $27.6 \mathrm{~b}$ & $90 \mathrm{~b}$ & $24 \mathrm{~b}$ & $118 \mathrm{~b}$ & $29.87 \mathrm{a}$ & $2.84 \mathrm{~b}$ \\
\hline $\begin{array}{l}\text { SBAJA } \\
9.59 \mathrm{a}\end{array}$ & 316 a & $31.5 \mathrm{a}$ & $32.2 \mathrm{a}$ & $120 \mathrm{a}$ & $36 \mathrm{a}$ & 156 a & $30.11 \mathrm{a}$ & $3.84 \mathrm{a}$ \\
\hline \multicolumn{9}{|c|}{2009 field trials } \\
\hline $\begin{array}{l}\text { Control } \\
7.65 \mathrm{~b}\end{array}$ & 315 a & $27.6 \mathrm{~b}$ & $28.8 \mathrm{~b}$ & $96 \mathrm{~b}$ & $20 \mathrm{~b}$ & $116 \mathrm{~b}$ & $30.12 \mathrm{a}$ & $3.06 \mathrm{~b}$ \\
\hline $\begin{array}{l}\text { SBAJA } \\
9.87 \mathrm{a}\end{array}$ & $314 \mathrm{a}$ & $31.4 \mathrm{a}$ & $32.7 \mathrm{a}$ & $124 \mathrm{a}$ & $33 a$ & $157 \mathrm{a}$ & $30.21 \mathrm{a}$ & $3.95 \mathrm{a}$ \\
\hline \multicolumn{9}{|c|}{2010 field trials } \\
\hline $\begin{array}{l}\text { Control } \\
7.34 \mathrm{~b}\end{array}$ & $310 \mathrm{a}$ & $27.2 \mathrm{~b}$ & $28.6 \mathrm{a}$ & $93 \mathrm{~b}$ & $27 \mathrm{~b}$ & $120 \mathrm{~b}$ & $30.31 \mathrm{a}$ & $2.94 \mathrm{~b}$ \\
\hline $\begin{array}{l}\text { SBAJA } \\
10.10 \mathrm{a}\end{array}$ & $311 \mathrm{a}$ & $31.6 \mathrm{a}$ & $32.7 \mathrm{a}$ & $128 \mathrm{a}$ & $42 \mathrm{a}$ & $170 \mathrm{a}$ & $30.22 \mathrm{a}$ & $4.04 \mathrm{a}$ \\
\hline
\end{tabular}

Means within the same column followed by the same letter do not differ significantly according to the LSD test at $\alpha=0.05$ 
This study revealed that foliar applications of SBAJA resulted in a significant increase in 1000 grain weight. This may be due to the provision of macro-and micronutrients at later stages, which might have enhanced the accumulation of assimilates in the grains and thus resulted in heavier grains of rice. Our results supported by the findings of Soylu et al. (2005) and Guenis et al. (2003) who reported a significant increase in 1000 grain weight with the foliar application of micronutrients. Foliar application may guarantee the availability of nutrients to rice for obtaining higher yield. Our large-scale extensive multi-location field trials with normal fertilizer applications augmented with SBAJA in 2008-20010 in the Selangor North West Project (SNWP), and greenhouse experiments registered measurable increase in rice yields by 25 $30 \%$ from $6.2-6.5$ tons/ha to $7.8-8.9$ tons/ha. Parallel figures in farmers-managed field trials with SBAJA in SNWP recorded yields ranging from $9.60-10.00$ tons/ha vis-à-vis $7.00-7.70$ tons/ha in plots receiving only normal NPK fertilizers. Some farmers secured yields as high as 10 tons/ha in Sungai Besar or 12 tons/ha in Sekinchan, Selangor when normal fertilizer applications were fortified with foliar sprays of SBAJA. Interestingly, SBAJA promotes better crop growth even in dry fields possibly due to better root productions in rice plants. Liew et al. (2010) reported that the application of special fertilizers in conjunction with proper filed maintenance increased the production of MR 219 by $27 \%$ from 4.62 tons per hectare to 5.87 tons per hectare.

\section{Socio-economic Impacts - SBAJA application on rice production, self-sufficiency level (SSL) and food security in Malaysia}

We believe that the national target of achieving national rice production from the current level of 2.30 million tons to 2.95 million tons can be achieved with extensive use of SBAJA by rice farmers in the country by 2010 to attain $86 \%$ level of SSL.

With an extra investment of only ca. RM200/ha on SBAJA, farmers can reap an extra net income of no less than RM 1,200 - 1,500/ha (Figure 3 ). Based on a minimal incremental yields of just 1 ton/ha/season from 100,000 ha of rice area, we projected a parallel increase of 200,000 tons/yr of rice valued at RM240 - RM300 million/year with input investment of RM80 million/year of SBAJA. In the same vein and based on 300,000 ha of rice fields using the standard fertilizer regimes but fortified with SBAJA foliar sprays, yield projections of 600,000 tons/year valued at RM 720 million RM 900 million/year (Figure 4). These yield figures are projected to meet $86 \%$ of SSL in rice by 2010 . We expect to achieve $100 \%$ SSL in rice by 2015 with wide usage of SBAJA by rice farmers in the country.

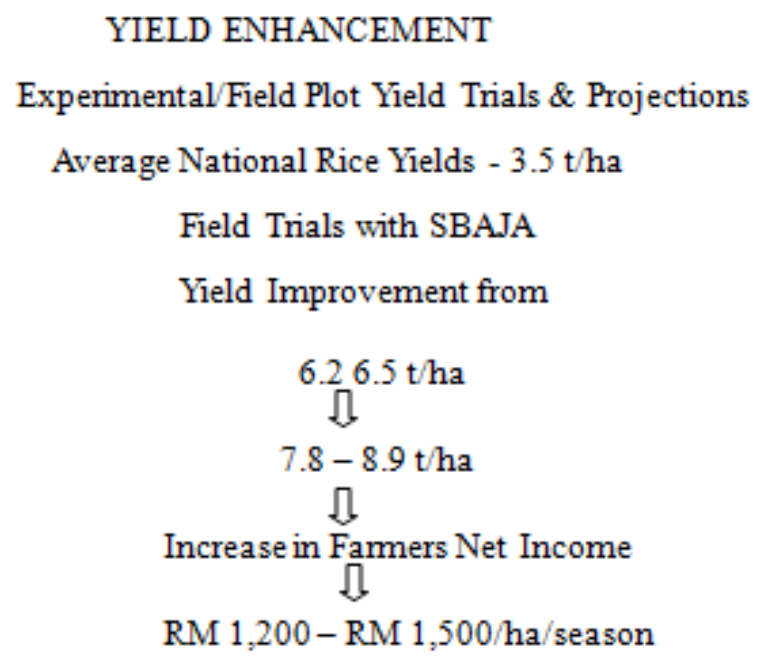

Figure 3. Mean increased production in rice tonnage following SBAJA applications and returns to farmers in Sungai Besar, Selangor, Malaysia 


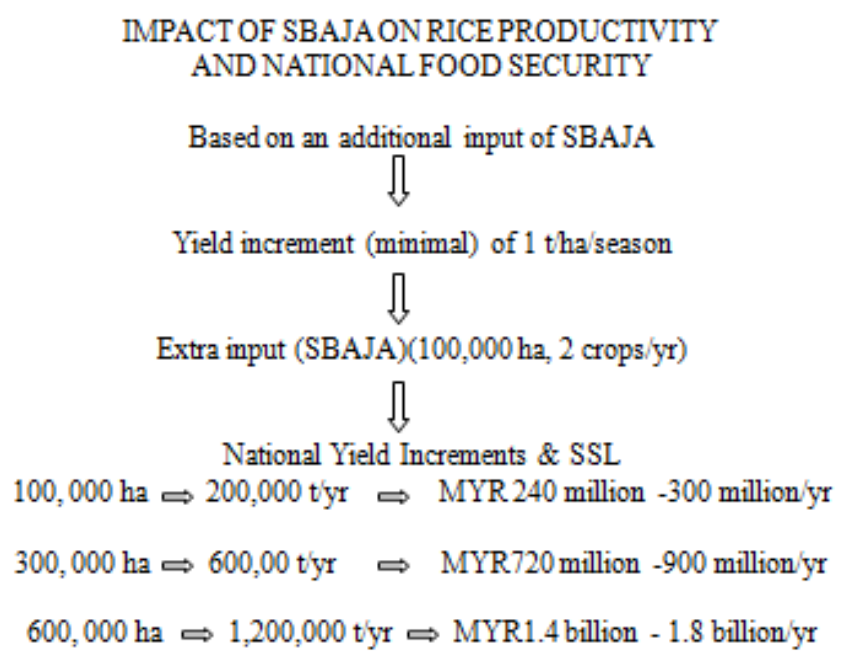

Figure 4. Impacts of SBAJA application on rice production, self-sufficiency level (SSL), and food security in Malaysia.

With an extra investment of only ca. RM 200/ha for SBAJA, farmers can reap an extra net income of MYR1,000 -1,500/ha. Based on a minimal incremental yield of just 1 ton/ha from 100,000 ha of rice area, we projected a parallel increase of 200,000 tons/yr of rice valued at MYR 200 million/yr with input investment of MYR 40 million of SBAJA. Parallel figures for 600,000 ha of effective rice growing areas treated with SBAJA would be rice production of 1,200,000 ton/yr valued at MYR1.4 billion - 1.8 billion/year not only contribute to national saving but also meeting the national SLL of $100 \%$ in rice supply by 2015 .

\section{CONCLUSIONS}

The tested dilution of SBAJA (1:300) can increase the growth and yield of rice (MR220) both green house and field conditions.

Foliar application of SBAJA increased the leaf chlorophyll content and net photosynthesis as well as productivity of rice. Tiller number per genete, panicle length, weight, number of grain in panicle, number of filled, unfilled and total number of grain was also increased by SBAJA treatment.
Additionally, 1000 grain weight and yield of rice increased significantly with spray treated of SBAJA.

We are confident that the adoption of SBAJA to augment normal fertilizer applications in rice fields by Malaysian farmers not only will help to achieve national SSL target in rice to meet domestic market demand, thus reducing dependence on foreign supply and import bills, but also meet the national needs of food security in the ensuing decades. We are equally confident that should SBAJA be adopted by farmers in the ASEAN region and beyond, food security in terms of rice supply for the growing populace can be met.

\section{ACKNOWLEDGEMENTS}

The authors thank the Ministry of Agriculture and Agro-based Industry Malaysia for the financial support under the Techno Fund Research Grant (TF003-2010) and Norhapipah Satam for her technical support. It is also acknowledge that we have no direct financial relation with the commercial identity of this product mention in the manuscripts.

RESUMO: Os testes de eficácia do produto durante 2006 a 2010 com SBAJA (um novo spray foliar cientificamente formulado) em estufa e ensaios de campo em várias localizações registraram aumento mensurável nos teores de clorofila, crescimento robusto e mais saudável das culturas e aumento do rendimento e da produção de biomassa. No ensaio de campo, plantas de arroz recebendo adubo NPK normal nas doses de 100:50:30 serviram como controle e foram tratadas com SBAJA aos 40 e 60 dias após a semeadura (DAS). Todos os experimentos foram dispostos no formato Randomized Complete Block (RCB) e replicados cinco vezes. Número de perfilhos e características da panícula; comprimento, peso, número de grãos, número de grãos preenchidos foram significativamente aumentados com 0 tratamento com 1:300 SBAJA. Além disso, o peso de 1000 grãos e o rendimento de arroz aumentaram significativamente 
com os tratamentos da SBAJA. Aplicações normais de fertilizantes em testes de campo aumentados com a SBAJA em 2008-2010 no Projeto Selangor North West (SNWP), registraram aumento mensurável na produção de arroz de 25-30\% de 6,2 a 6,5 toneladas/ha para 7,8 a 8,9 toneladas/ha. Conclui-se que a pulverização foliar com SBAJA aos 40 e 60 dias após a semeadura aumentou o crescimento e o rendimento do arroz em estufa e em campo.

PALAVRAS-CHAVE: SBAJA. Crescimento. Rendimento. Arroz. Malásia.

\section{REFERENCES}

ARNON, D. L. A copper enzyme is isolated chloroplast polyphenol oxidase in B. vulgaries.

Plant Physiology, v. 24, n. 1, p. 1-15, 1949.

BAMBARADENIYA, C. N. B.; AMERASINGHE, F. P. Biodiversity associated with rice fieldagrosystems in Asian countries: a brief review. International Water Management Institute, Working paper, p. 29-63, 2003. http://hdl.handle.net/10535/4794

CHEN, X.; YUAN, H.; CHEN, R., ZHU, L.; DU, B.; WENG, Q.; HE, G. Isolation and characterization of triacontanol regulated genes on rice (Oryza sativa $\mathrm{L})$ : possible role of triacontanol as plant growth stimulators. Plant Cell Physiology, v. 43, n. 8, p. 869-876, 2002. PMID: 12198189

CHOPRA, N. K.; CHOPRA, N. Seed yield and quality of "Pusa 44" rice (Oryza sativa L) as influenced by nitrogen fertilizer and raw spacing. Indian Journal of Agricultural Science, v. 74, n. 1, p. 144-146, 2004. http://www.innspub.net

DOBERMANN, A. C.; WITT, B.; DAWE, D. Increasing productivity of intensive rice systems through sitespecific nutrient management. International Rice Research Institute Handbook Series. Los Banos, (Philippines): International Rice Research Institute, Science Publishers, Inc. , 2004.

DEFAN, T. A.; KHOLI, H. M. A.; RIFAAT, M. G. M.; ALLAAH, A. E. A. Effect of foliar and soil application of potassium on yield and mineral content of wheat grains grown in sandy soils. Egyptian Journal of Agricultural Research, v. 77, n. 2, p. 513-522, 1999.

ESFEHANI, M.; SADRZADADE, S.M.; KAVOOSI, M.; DABAGH-MOHAMMAD-NASAB, A. Study the effect of different levels of nitrogen and potassium fertilizers on growth, grain yield, yield components of rice (Oryza sativa) cv. Khazar. Iranian Agronomy Journal, v. 7, p. 226-241, 2005.

FANG, L.; WANG, L.; XIN, Z.; ZHAO, L.; AN, X.; HU, Q. Effect of foliar application of zinc, selenium, and iron fertilizers on nutrients concentration and yield of rice grain in China. Journal of Agriculture, Food and Chemistry, v. 56, n. 6, p. 2079-2084, 2008. https://doi.org/10.1021/jf800150z

GUENIS, A.; ALPASLAN, M.; UNAL, A. Effects of boron fertilization on the yield and some yield components of bread and durum wheat. Turkish Journal of Agriculture and Forestry, v. 27, p. 329-335, 2003. () TÜBITAK

HANSEN, P. M.; SCHJOERRING, J. K. Reflectance measurement of canopy biomass and nitrogen status in wheat crops using normalized difference vegetation indices and partial least squares regression. Remote Sensing and Environment, v. 86, n. 4, p. 542-553, 2003. https://doi.org/10.1016/S0034-4257(03)00131-7

HAQ, M. U.; MALLARINO, A. P. Soybean yield and nutrient composition as affected by early-season foliar fertilization. Journal of Agronomy, v. 92, n. 1, p. 16-24, 2000. https://doi.org/10.2134/agronj2000.92116x

ISLAM, M. S.; HASANUZZAMAN, M.; ROKONUZZAMAN, M.; NAHAR, K. Effect of split application of nitrogen fertilizer on morph physiological parameters of rice genotypes. International Journal of Plant Production, v. 3, n. 1, p. 51- 61, 2009. www.ijpp.info 
IRRI. Bringing hope, improving lives: strategic plan, 2007-2015. Manila (Philippines), p. 61, 2006.

IRRI. Background Paper: The rice crisis: What needs to be done? Los Baños (Philippines), p. 12, 2008.

IVANOV, G. A.; ANGELOV, M. N. Photosynthesis response to triacontanol correlates with increased dynamics of mesophyll protoplast and chloroplast membranes. Plant Growth Regulation, v. 21, p. 145-152, 1997.

JAMAL, Z.; HAMAYUN, M.; AHMAD, N.; CHAUDHARY, M. F. Effect of soil and foliar application of different concentrations of NPK and foliar application of $\left(\mathrm{NH}_{4}\right)_{2} \mathrm{SO}_{4}$ on different parameters in wheat. Journal of Agronomy, v. 5, n. 2, p. 251-256, 2006.

KENBAEV, B.; SADE, B. Response of field-grown barley cultivars grown on zinc-deficient soil to zinc application. Communication in Soil Science and Plant Anatomy, v. 33, n. 3-4, p. 533-544, 2002. https://doi.org/10.1081/CSS-120002762

KHANDAKER, M. M.; FARUQ, G.; MOTIOR, M. R.; SOFIAN- AZIRUN, M.; BOYCE, A. N. The Influence of 1-Triacontanol on the Growth, Flowering and Quality of Potted Bougainvillea Plants (Bougainvillea glabra var. Elizabeth angus ) Under Natural Conditions. The Scientific World Journal, V. 2013, Article ID 308651, p.1-12, 2013a. DOI.org/10.1155/2013/308651

KHANDAKER, M. M.; BOYCE, A. N.; NORMANIZA, O.; FARUQ, G.; MOTIOR RAHMAN, M.; SOFIAN-AZIRUN, M. Fruit development, pigmentation and biochemical properties of wax apple as affected by localized application of GA3. Brazilian Achieves of Biology and Technology, v.56, n.1, p.11-20, 2013b.

KHANDAKER, M. M.; BOYCE, A. N.; NORMANIZA, O.; HOSSAIN, A. B. M. S. Physiochemical and phytochemical properties of wax apple (Syzygium samarangense [Blume] Merrill \& L.M. Perry) as affected by growth regulator application under field conditions. The Scientific World Journal, v. 2012, p.1-13, 2012. doi:10.1100/2012/728613.

KOLOTA, E.; OSINSKA, M. Efficiency of foliar nutrition of field vegetables grown at different nitrogen rates. In: Proc. IC Environ. Problems of Nitrogen Fertilizer and Acta Horticulturae, v. 563, p. 87-91, 2001.

LIN, X.; ZHU, DF. Effects of regent on growth and yield in rice. Acta Agril Zhejiangensis, v. 12, n. 2, p. 70 73,2000 .

LIEW, Y. A.; SYED- OMAR, S. R.; HUSNI, M. H. A.; ZAINAL, A. M. A. ABDULLAH, N. A. P. Effects of Micronutrient Fertilizers on the Production of MR 219 Rice (Oryza sativa L.) Malaysian Journal of Soil Science, v. 14, p. 71-82, 2010.

MONERUZZAMAN, K. M.; HOSSAIN, A. B. M. S.; NORMANIZA, O.; SAIFUDIN, M.; SANI, W.; AMRU N. B. Effects of removal of young leaves and cytokinin on inflorescence development and bract enlargement in Bougainvillea glabra var. "Elizabeth Angus". Australian Journal of Crop Science, 4 (7) 467-473, 2010.

NICOULAUD, B. A. L.; BLOOM, A. J. Absorption and assimilation of foliar applied urea in tomato. Journal of American Society of Horticultural Science, v. 121, n. 6, p. 1117-1121,1996.

PENG, S.; CASSMAN, K. G.; KROPFF, M. J. Relationship between leaf photosynthesis and nitrogen content of field-grown rice in the tropics. Crop Science, v. 35, n. 6, p. 1627-1630, 1995.

https://doi.org/10.2135/cropsci1995.0011183X003500060018x

RIES, S. K. Regulation of plant growth with triacontanol. Critical Review in Plant Science, v. 2, n. 3, p. 239285, 1985. https://doi.org/10.1080/07352688509382197

SHAH, K. H.; SAEED, M. Effect of combination of soil and foliar application of urea on three wheat genotypes. Pakistan Journal of Science and Industrial Research, v. 32, n. 12, p. 813-815, 1989. 
SULTANA, N.; IKEDA, T.; KASHEM, M. A. Effect of foliar spray of nutrient solutions on photosynthesis, dry matter accumulation and yield in seawater-stressed rice. Environmental and Experimental Botany, v. 46, n. 2, p. 129-140, 2001. https://doi.org/10.1016/S0098-8472(01)00090-9

SOYLU, S.; SADE, B.; TOPAL, A.; AKGUN, N.; GEZGIN, S. Responses of irrigated durum and bread wheat cultivars to boron application in low boron calcareous soil. Turkish Journal of Agriculture and Forestry, v. 29, n. 4, p. 275-286, 2005.

SADANA, U. S.; LATA, K.; ClAASSEN, N. Manganese efficiency of wheat cultivars as related to root growth and internal manganese requirement. Journal of Plant Nutrition, v. 25, n. 12, p. 2677-2688, 2002.

TEJADA, M.; GONZALEZ, J. L. Effects of foliar application of a by product of the two-step olive oil mill process on rice yield. European Journal of Agronomy, v. 21, n. 1, p. 31- 40, 2004. 